\title{
Assessment of Level of HIV/AIDS Preventive Self- Efficacy and Associated Factors Among Regular Undergraduate Students of Madda Walabu University, Southeast Ethiopia, 2020. A Cross-Sectional Study
}

\section{Chala Kene}

Madda Walabu University

Haweni Adugna

Addis Ababa University College of Health Sciences

Kalkidan Lemessa

Selale University College of health science

Leul Deribe ( $\nabla$ leul.deribe@gmail.com )

Addis Ababa University https://orcid.org/0000-0003-3379-3046

\section{Research}

Keywords: HIV/AIDS, University Students, Self-efficacy

Posted Date: November 4th, 2020

DOI: https://doi.org/10.21203/rs.3.rs-99726/v1

License: @ (1) This work is licensed under a Creative Commons Attribution 4.0 International License. Read Full License 


\section{Abstract}

Background: Self-efficacy for HIV prevention is described as a person's belief in his/her capacity to carry out necessary actions to perform a specific behavior for HIV prevention. This study aimed to assess level of HIV/AIDS preventive self-efficacy and associated factors among regular undergraduate students of Madda Walabu University, Southeast Ethiopia, 2020.

Methods: Cross-sectional study was conducted from February 15 to 20, 2020. Four hundred forty-two study participants were selected using simple random sampling technique. Data was entered to Epi Data version 4.6.0.2 and analyzed using SPSS version 26 software. Bivariate and multivariable logistic regression model was fitted to identify factors associated with HIV/AIDS preventive self-efficacy. Odds ratio with $95 \%$ confidence interval was computed and $p$ value less than 0.05 was used to determine the level of significance.

Result: The mean level of HIV/AIDS preventive self-efficacy among regular undergraduate students of Madda Walabu University was found to be 74.58 \pm 19.98 . Being female [AOR=1.76(1.04-2.81)], in field of health science $[A O R=1.92(1.10-3.36)]$, second year of study [AOR=2.77(1.55-4.94)] and drinking alcohol [AOR=2.9(1.61-5.23)] were found to be factors associated with higher HIV/AIDS preventive self-efficacy. Whereas, exposed to pornography $[A O R=0.53(0.33-0.85)]$ was found to be factor associated with lower HIV/AIDS preventive selfefficacy.

Conclusion: The mean HIV /AIDS preventive self-efficacy of the participants in this study area were found to be low. Sex, field and year of study, drinking alcohol and ever had watched pornography were factors found to be significantly associated with HIV/AIDS preventive self-efficacy. Staffs should be cooperative in educating their students to boost their self-efficacy.

\section{Plain English Summary}

Self-efficacy related to the individuals' beliefs in their abilities to have more control over their motives, behaviors, and most importantly, over their social environment. As university students may engage in risky behavior, HIV preventive self-efficacy helps to learn and utilize effective method of HIV prevention. However, there were limited evidences on level of HIV/AIDS preventive self-efficacy and factors associated in the study area. This study is conducted to assess level of HIV/AIDS preventive self-efficacy among Mada Wallabu university students, Ethiopia using cross-sectional study.

Four hundred forty-two study students were selected using simple random sampling technique. To examine HIV preventive self-efficacy, the Self-Efficacy scale for AIDS (SEA-27) was used. The overall mean of HIV/AIDS preventive self-efficacy were found to be 74.58 with standard deviation of 19.98. it was $71.38(S D=18.0)$ for male and 81.21 ( $S D=22.18)$ for female students. About half $(51 \%)$ of the students were found to have greater than mean value. Being female, health science student, second year of study and drinking alcohol were found to be associated with higher HIV/AIDS preventive self-efficacy. Whereas, student's exposure to pornography had lower HIV/AIDS preventive self-efficacy. It is recommended that multisectoral effort is needed to improve HIV preventive self-efficacy of university students in order to decrease the burden of the disease.

\section{Background}


Self-efficacy concept derived from Bandura's social-cognitive theory, considers individual's insights of their own capabilities to play a key role in changing their behaviors, motivations and experiences ${ }^{(1)}$. It is one of the crucial components in learning effective behavior for dealing with AIDS crisis since many students engage in high risk sexual behavior even if they are aware of the risks. Enhancing self-efficacy for reducing HIV/AIDS-related risk behaviors is a critical element for HIV preventive programs among adolescence ${ }^{(2)}$. Therefore, self-efficacy for HIV prevention is described as a person's belief in his/her capacity to carry out necessary actions to perform a specific behavior for HIV prevention. It is being strongest predictors for HIV prevention ${ }^{(3)}$.

In 2018, 510,000 adolescents below the age of 24 were newly infected with HIV worldwide and projected to rise from 250,000 in 2015 to nearly 400,000 annually by 2030 if progress in reaching adolescents stalls ${ }^{(4)}$. In SubSaharan Africa these case seems serious which $89 \%$ of HIV cases were adolescents and girls being newly infected at four times the rate of adolescent boys ${ }^{(5)}$. In Ethiopia $30 \%$ of university students, both male and female, were sexually active and they were at risk of complications related to unsafe sex such us STI including HIV and abortion ${ }^{(6)}$.

University students are very mobile group, and if not protected and preserved from the scourge of HIV and AIDS, they can become dispersal agents for the spread of HIV in society ${ }^{(7)}$. They are at higher risk of engaging in risky sexual behavior, especially if they are under the influence of alcohol or drugs and lack the necessary maturity in handling negative peer pressure ${ }^{(8)}$.

Students with lower self-efficacy have less control over their lives and are more likely to be subjected to highrisk behaviors. In sum, low self-efficacy of the students can destroy their motivation, interfere with cognitive abilities and increase the possibility of high-risk behaviors and vulnerability for HIV infection ${ }^{(9)}$. For instance the study found students with low condom efficacy had a higher risk of inconsistent condom use with a new sex partner ${ }^{(10)}$.

According to study conducted on Mexican adolescence the level of HIV/AIDS preventive self-efficacy was found to be $95.14(S D \pm 25.80)^{(11)}$. Other study conducted on Turkey university students showed that the mean level of HIV/AIDS preventive self-efficacy was $87.66(S D \pm 23.94)^{(12)}$ and further study conducted on Tawenness adolescence reported the mean level of $74.45(\mathrm{SD} \pm 17.05)^{(13)}$.

In Ethiopian universities, students were reported to be engaged in different risk activities which facilitate the infection to increase. For instance in Debre Berhan University, $(25.13 \%)$ students have at least one risky sexual behavior in their lifetime in which cigarette smoking and pornography exposure shows significant association with risky sexual behavior ${ }^{(14)}$ and in Bahir Dar University, having sex after alcohol drinking and khat chewing ,watching pornography and inconsistent use of condom were the risk factors for HIV infection ${ }^{(15)}$. In addition, a qualitative study carried out in higher educational institution of Ethiopia revealed that substance abuse and addictions, early initiation of sex, and exposure to pornography were reported as a problem for the increase HIV infection ${ }^{(16)}$. Furthermore, other study found that characteristics of university students like; their age, ambition, experience of new events ${ }^{(17)}$, and other contextual driving factors, increase their exposure to HIV/ AIDS (18).

Hence, keeping in mind high-risk behaviors of university students and their potential risk for all society, assessing their preventive self-efficacy regarding HIV/AIDS may be helpful in identifying their potential ability to 
engage in risk reduction behaviors. However, no study was found on HIV/AIDS preventive self-efficacy in Ethiopia in general and in the study area particularly. Thus, this study was aimed to assess level of HIV preventive self -efficacy and associated factors among undergraduate regular students at the study area.

\section{Methods And Materials}

\section{Study settings}

An institutional cross- sectional study design was conducted among undergraduate regular students of Madda Walabu University from February 15 to 20,2020 . The university was established in 2006 . According to the data obtained from the registrar record office in 2020 , the university had three campuses namely Robe, Goba and Shashamane. In 2020, the university had a total number of 9253 regular undergraduate students with 50 undergraduate programs, eight schools, one institute and two colleges of health sciences ${ }^{(19)}$. All regular undergraduate students at Madda Walabu University were source population, whereas randomly selected voluntary students who attended class at data collection period were study population.

\section{Sample size determination and Sampling procedure}

Sample size was calculated using sample size for single population proportion formula. After exhaustive searching, the principal investigator was not found study done previously on university students regarding HIV preventive self-efficacy either in Ethiopia or study area. Therefore, the assumption of, 50\% proportion, $95 \% \mathrm{Cl}$ and $5 \%$ degree of precision was used to calculate the sample size. After adding $15 \%$ non-response rate, the final sample size was found to be 442. From the total eight schools in Robe campus, six schools were selected randomly and Goba and Shashamane Collage of Health Sciences were included. Sample size was allocated proportionally for each schools and colleges. The total number of students under selected schools and collages were 5680. The students were stratified for selected schools in Robe Campus and both collages of health sciences. Then students were further stratified in class years. Finally, simple random sampling was implemented using students list obtained from registrar as sampling frame.

\section{Data Collection Procedure and Instrument}

Data was collected through self administered questionnaire prepared in English language, since language of instruction in Ethiopian higher inistitutions is Eglish. Four diploma nurses were asigned as data collectors and three Bsc instructors with previouse research experience were assigned as supervisors.

To examine HIV preventive self-efficacy among students, the Self-Efficacy scale for AIDS (SEA-27) AIDSPrevention Self-efficacy scale was used. The scale has 27 five-point Likert scale consisting, 1 = "not at all sure", 2 = "a little sure", 3 = "somewhat sure", 4 = "pretty sure" and 5 = "Very sure". It evaluates self-efficacy with the Bandura's socio-cognitive theory, in three aspects of sex-related behavior: ability to say no to sexual intercourse under different circumstances, ability to ask partner about previous sexual relations and other risk behaviors such as drug use and perceived ability to acquire and correctly use condoms ${ }^{(12)}$.

Initially Kasen, Vaughan \& Walter developed scale with 22 items as measuring HIV/AIDS preventive selfefficacy among adolescents between ages 15 and 19; in that study the internal consistency of this scale was high $(a=.91)^{(20)}$. The scale was tested again on a large sample group of high school students and some items 
of the scale were modified, and the number of items was increased from 22 to 27 . Internal consistency of the 27 -item self-efficacy scale was found to be 0.89 in study done on Mexican Youth ${ }^{(11)}$. In this study, the last version of the Self-Efficacy scale for AIDS (SEA-27) tested on Turkey University Students and reported with internal consistency of 0.93 was used ${ }^{(12)}$. Yet; one question which asks about homosexual was excluded in Ethiopian context. Students who has scored above mean value will be considered as having good preventive self-efficacy.

Believes assessment tool was developed from literatures pertinent to the topics ${ }^{(21)}$ (22). In addition, the tool for assessing risk behavior was adopted from literature reviewed pertinent to the topic (23) (17) and from standard questionnaires designed by Family Health International for Behavioral Surveillance Survey(BSS) on high-risk behavior for HIV-1 ${ }^{(24)}$. Level of HIV/AIDS knowledge was assessed using HIV Knowledge Questionnaire (HIVKQ) with internal consistency reliability analysis of HIV-KQ $(N=1033)(a=.91){ }^{(25)}$ and internal consistency reliability as measured by Kuder-Richardson formula(KR-20) $(a=0.58)(n=483)$ and test-retest $0.59(n=39)(26)$. Students who scored above mean score will be considered as having good knowledge.

\section{Data quality assurance}

Pretest was done in $5 \%$ of the sample size in non-selected department of Madda Walabu University, in order to check the clarity of the tool and allocate time needed for filling the questionnaires. Training was provided for data collectors and supervisors. Through the course of data collection, the data collectors were supervised and there was regular phone contact between principal investigator and data collectors to know the data collection progress. Incomplete data were discarded and considered as non-response. The data was said to be incomplete when half of the items in each section were not filled. Therefore, twelve questionnaires were discarded based on this criterion. Finally, the collected data was reviewed and checked for full completeness before data entry.

\section{Data processing and Analysis}

The data was coded and entered to Epi Data 4.6.0.2. Then exported to SPSS version 26 and cleaned before analysis. Descriptive statistics was calculated for the variables. Statistical significance and strength of the association between independent variables and outcome variables was measured by using logistics regression model. A variable $P$ value less than 0.2 and important variable was transferred to multivariable logistics regression model to adjust confounder's effects. A p value less than 0.05 were considered as significantly associated. Crude and adjusted odds ratios with their $95 \%$ confidences intervals was calculated. Finally, the result of the study was presented using tables, graph, chart and texts based on the data obtained.

\section{Result}

In this study, 442 students were approached and a total 430 responded fully yielding response rate of $97.3 \%$ whereas the remaining $2.7 \%$ non-responses were due to incomplete data.

\section{Socio-demographic characteristics of the respondents}

Most of the participants 308 (71.6\%) were Oromo by ethnicity followed by Amhara 73 (17.0\%). Mean age of the participants was 21.93 (SD 1.91) with range of 18 to 28 . Majority 393(91.4\%) of participant were between age 
of 18-24. Of total respondents, 290(67.4\%) were male, 314(73.0\%) belongs to non-health field of study, $173(40.2 \%)$ were year III students and $63(14.7 \%)$ of them were in sexual relationship (Table 1). 
Table 1

Socio-demographic characteristics of the regular undergraduate students of Madda Walabu University Bale Zone, Southeast Ethiopia February 15-20/2020.

\begin{tabular}{|c|c|c|}
\hline Variables & Frequency & $\%$ \\
\hline $\begin{array}{l}\text { Sex } \\
\text { Female }\end{array}$ & 140 & 32.6 \\
\hline Male & 290 & 67.4 \\
\hline $\begin{array}{l}\text { Age } \\
18-24\end{array}$ & 393 & 91.4 \\
\hline$>=25$ & 37 & 8.6 \\
\hline $\begin{array}{l}\text { Marital status } \\
\text { Single }\end{array}$ & 367 & 85.3 \\
\hline In sexual relationship & 63 & 14.7 \\
\hline $\begin{array}{l}\text { Origin or residence } \\
\text { Urban }\end{array}$ & 225 & 52.3 \\
\hline Rural & 205 & 47.7 \\
\hline $\begin{array}{l}\text { Religion } \\
\text { Orthodox }\end{array}$ & 199 & 46.3 \\
\hline Muslim & 103 & 24.0 \\
\hline Protestant & 113 & 26.3 \\
\hline Other* & 15 & 3.5 \\
\hline $\begin{array}{l}\text { Ethnicity } \\
\text { Oromo }\end{array}$ & 308 & 71.6 \\
\hline Amhara & 73 & 17.0 \\
\hline Tigrean & 14 & 3.3 \\
\hline Other** & 35 & 8.1 \\
\hline $\begin{array}{l}\text { Field of study } \\
\text { Health science }\end{array}$ & 116 & 27.0 \\
\hline Non- health science & 314 & 73.0 \\
\hline
\end{tabular}

Key: Other* Waqeffatta, Catholic, Adventist

Other** Sidama, Sheka, Woleytta, Silte, Sumale 


\begin{tabular}{|c|c|c|}
\hline Variables & Frequency & $\%$ \\
\hline Year of study & 119 & 27.7 \\
\hline \multicolumn{3}{|l|}{ ॥ } \\
\hline III & 173 & 40.2 \\
\hline IV and above & 138 & 32.1 \\
\hline $\begin{array}{l}\text { Monthly income from family or relatives in birr. } \\
<300 \text { birr }\end{array}$ & 96 & 22.3 \\
\hline$>300$ birr & 278 & 64.7 \\
\hline Don't remember & 56 & 13.0 \\
\hline $\begin{array}{l}\text { Preparatory school accomplishing } \\
\text { Governmental }\end{array}$ & 354 & 82.3 \\
\hline Non-governmental & 76 & 17.7 \\
\hline \multicolumn{3}{|l|}{ Key: Other* Waqeffatta, Catholic, Adventist } \\
\hline \multicolumn{3}{|l|}{ Other** Sidama, Sheka, Woleytta, Silte, Sumale } \\
\hline
\end{tabular}

Three-fourth of the participants 326 (75.8\%) believed that person who had more knowledge on HIV/AIDS have high preventive self-efficacy than person with low knowledge. Being followed by statement, having life goal increase HIV/AIDS preventive self-efficacy of the students, 315(73.3\%). Half (215(50\%)) of the respondent answered 'yes' to the statement condom use implies distrust/insult in one's partner (Table 2). 
Table 2

Believe on HIV/AIDS preventive self-efficacy among regular undergraduate students of Madda Walabu University Bale Zone, Southeast Ethiopia February15-20/2020.

\begin{tabular}{|llll|}
\hline Variables & Options & Fre & $\%$ \\
\hline $\begin{array}{l}\text { Do you believe that during stay in university, having life goal increase HIV/AIDS } \\
\text { preventive self-efficacy of the students? }\end{array}$ & Yes & 315 & 73.3 \\
\cline { 2 - 3 } & No & 115 & 26.7 \\
\hline $\begin{array}{l}\text { Do you believe that person who had more knowledge on HIV/AIDS have high } \\
\text { preventive self-efficacy than person with low knowledge? }\end{array}$ & Yes & 326 & 75.8 \\
\cline { 2 - 3 } & No & 104 & 24.2 \\
\hline $\begin{array}{l}\text { Do you believe that having spoken with someone other than parent or guardian } \\
\text { about HIV/AIDS increase HIV/AIDS preventive self-efficacy? }\end{array}$ & Yes & 266 & 61.9 \\
\hline $\begin{array}{l}\text { Do you believe that condom use implies distrust/insult in one's partner? } \\
\text { No }\end{array}$ & Yes & 2154 & 38.1 \\
\hline $\begin{array}{l}\text { Do you believe that getting condom easily increase HIV/AIDS preventive self- } \\
\text { efficacy? }\end{array}$ & No & 215 & 50.0 \\
\hline
\end{tabular}

\section{Risk behavior of the respondents}

As shown in Table 3, regarding substance use, 100(23.3\%), 78(18.1\%) and 45 (10.5\%) participants drunk alcohols, chewed chat and smoked cigarette respectively. During staying in campus 57(13.3\%) participants had tried different ranges of drugs in which 22(5.1\%) tried cocaine, 20(4.7\%) tried shisha/gaya and 15(3.5\%) had tried hashish (Table 3). 
Table 3

Substance use risk behaviors for having HIV/AIDS among regular undergraduate students of Madda Walabu University Bale Zone, Southeast Ethiopia February 1520/2020.

\begin{tabular}{|c|c|c|}
\hline Variables & Frequency & $\%$ \\
\hline \multicolumn{3}{|l|}{ Had smoked cigarette } \\
\hline Yes & 45 & 10.5 \\
\hline \multicolumn{3}{|l|}{ How often you smoked } \\
\hline Everyday & 7 & 1.6 \\
\hline At least once a week & 25 & 5.8 \\
\hline Less than once a week & 8 & 1.9 \\
\hline Don't remember & 4 & 0.9 \\
\hline No response & 1 & 0.2 \\
\hline \multicolumn{3}{|l|}{ Chewed chat } \\
\hline Yes & 78 & 18.1 \\
\hline \multicolumn{3}{|l|}{ How often you chewed } \\
\hline Everyday & 25 & 5.8 \\
\hline At least once a week & 24 & 5.6 \\
\hline Less than once a week & 13 & 3.0 \\
\hline Don't remember & 10 & 2.3 \\
\hline No response & 6 & 1.4 \\
\hline \multicolumn{3}{|l|}{ Drinking alcohols } \\
\hline Yes & 100 & 23.3 \\
\hline \multicolumn{3}{|c|}{ How often you drinking alcohols } \\
\hline Everyday & 1 & .2 \\
\hline At least once a week & 41 & 9.5 \\
\hline Less than once a week & 27 & 6.3 \\
\hline Don't remember & 27 & 6.3 \\
\hline No response & 4 & .9 \\
\hline \multicolumn{3}{|c|}{ Tried to use different range drugs } \\
\hline Yes & 57 & 13.3 \\
\hline Types of drugs & & \\
\hline
\end{tabular}




\begin{tabular}{|lll|}
\hline Variables & Frequency & $\%$ \\
\hline Shisha/Gaya & 20 & 4.7 \\
\hline Hashish & 15 & 3.5 \\
\hline Cocaine & 22 & 5.1 \\
\hline Go to night clubs & & \\
\hline Yes & 37 & 8.6 \\
\hline How often you go to clubs & & \\
\hline Everyday & 4 & .9 \\
\hline At least once per week & 13 & 3.0 \\
\hline Less than once per week & 10 & 2.3 \\
\hline Don't remember & 8 & 1.9 \\
\hline No response & 2 & .5 \\
\hline
\end{tabular}

As showed in Fig. 1, among the total respondents, around 262(60.9\%) ever had tested for HIV in which 95(22.1\%) test was done more than a year ago (Fig. 1).

Of $160(37.2 \%)$ sexually active participants, only $30(7 \%)$ of them used condom in their first sexual contact. The mean ages at first sexual intercourse of the participants were 18.21 (SD 2.113), in which it was 18.55 (SD 2.11) for males and 17.28 (SD 1.89) for females. Regarding sexual partners, 42(9.8\%) participants ever had more than two sexual partners in their lifetime's and 11(2.6\%) had more than two current sexual partners. Among participants ever had sexual intercourse, 23(5.3\%) reported having sex while drinking alcohol and $13(3.0 \%)$ had sex while using psychoactive drugs (Table 4). 
Table 4

Risk sexual behaviors for HIV infection among regular undergraduate students of Madda Walabu University Bale Zone, Southeast Ethiopia February 1520/2020.

\begin{tabular}{|c|c|c|}
\hline Variables & Frequency & $\%$ \\
\hline \multicolumn{3}{|c|}{ Ever had sexual intercourse } \\
\hline Yes & 160 & 37.2 \\
\hline \multicolumn{3}{|c|}{ Used condom in first sexual intercourse } \\
\hline Yes & 30 & 7.0 \\
\hline No & 130 & 30.2 \\
\hline \multicolumn{3}{|c|}{ Number of sexual partner in lifetimes } \\
\hline One & 58 & 13.5 \\
\hline Two & 34 & 7.9 \\
\hline More than two & 42 & 9.8 \\
\hline Don't remember & 12 & 2.8 \\
\hline No response & 14 & 3.3 \\
\hline \multicolumn{3}{|c|}{ Current number of sexual partners } \\
\hline One & 95 & 22.1 \\
\hline Two & 31 & 7.2 \\
\hline More than two & 11 & 2.6 \\
\hline Don't remember & 6 & 1.4 \\
\hline No response & 17 & 4.0 \\
\hline \multicolumn{3}{|c|}{ Sexual contact with person greater at least 10 years old } \\
\hline Yes & 7 & 1.6 \\
\hline Used condom & 2 & .5 \\
\hline Not used condom & 5 & 1.2 \\
\hline \multicolumn{3}{|c|}{ Sexual contact with CSW (for male only) } \\
\hline Yes & 5 & 1.2 \\
\hline Used condom & 5 & 1.2 \\
\hline Not used condom & 0 & 0.0 \\
\hline Had sex while drink & & \\
\hline
\end{tabular}

Key: CSW; commercial sex workers 


\begin{tabular}{|l|llc|}
\hline \multicolumn{1}{|l}{ Variables } & Frequency & $\%$ \\
\hline Yes & 23 & 5.3 \\
\hline Had sex while using psychoactive drugs & & \\
\hline Yes & 13 & 3.0 \\
\hline No & 417 & 97.0 \\
\hline Ever watched pornography & & \\
\hline Yes & 167 & 38.8 \\
\hline No & 263 & 61.2 \\
\hline Key: csw; commercial sex workers & & \\
\hline
\end{tabular}

A total of 20 questions were used to measure level of HIV/AIDS knowledge among participants. The value 1 is given for those who answered yes (correctly) and 0 for those who answered no (incorrectly). Questions with opposite statements were recoded. The sum of these questions was obtained to range from 4 to 20 with mean HIV/AIDS knowledge of 13.60 and SD of 3.74. Of total participants, only 23 participants were answered all questions in correct manner.

As indicated in the Table 5, 344(80.0\%), 304(70.7\%) and 298(69.3\%) respondents were answered 'correctly' to the question that asked if condoms are $100 \%$ effective in preventing HIV, if they can get HIV from a mosquito bite and if all pregnant women infected with HIV will have babies born with AIDS respectively (Table 5). 
Table 5

HIV /AIDS Knowledge among regular undergraduate students of Madda Walabu University Bale Zone, Southeast Ethiopia February $15-20 / 2020(n=430)$.

\begin{tabular}{|c|c|c|c|}
\hline \multirow[t]{2}{*}{ S.No } & \multirow[t]{2}{*}{ Variables } & \multicolumn{2}{|c|}{$\begin{array}{l}\text { Correctly } \\
\text { answered }\end{array}$} \\
\hline & & Freq & $\%$ \\
\hline 1 & You can't get AIDS if you have sex only once or twice without a condom. & 322 & 74.9 \\
\hline 2 & $\begin{array}{l}\text { A person can "pass" an HIV antibody test (test negative) but still be infected with } \\
\text { HIV. }\end{array}$ & 172 & 40.0 \\
\hline 3 & Condoms are $100 \%$ effective in preventing HIV. & 344 & 80.0 \\
\hline 4 & Males can pass HIV on to others through their semen. & 219 & 50.9 \\
\hline 5 & You can get HIV by sitting on the seat of a toilet that a person with AIDS has used. & 326 & 75.8 \\
\hline 6 & $\begin{array}{l}\text { Abstinence from sex and drugs is the best way for adolescences to avoid getting } \\
\text { HIV. }\end{array}$ & 240 & 55.8 \\
\hline 7 & $\begin{array}{l}\text { You can get HIV from drinking from the same glass or water fountain that a } \\
\text { person with AIDS drank from. }\end{array}$ & 291 & 67.7 \\
\hline 8 & HIV can be found in semen, vaginal fluids, and blood & 332 & 77.2 \\
\hline 9 & A person can get HIV by sharing drug needles & 352 & 81.9 \\
\hline 10 & HIV can be found in breast milk. & 302 & 70.2 \\
\hline 11 & Once you are infected with HIV, you are infected for life. & 306 & 71.2 \\
\hline 12 & People infected with HIV are usually very thin and sickly & 227 & 52.8 \\
\hline 13 & $\begin{array}{l}\text { Some people have gotten HIV by swimming in the same pool as someone with } \\
\text { AIDS. }\end{array}$ & 291 & 67.7 \\
\hline 14 & You can get HIV from a mosquito bite. & 304 & 70.7 \\
\hline 15 & $\begin{array}{l}\text { Taking a test for HIV one week after having sex will tell a person if she or he has } \\
\text { HIV }\end{array}$ & 295 & 68.6 \\
\hline 16 & $\begin{array}{l}\text { Having sex with more than one partner can increase a person's chance of being } \\
\text { infected with HIV }\end{array}$ & 273 & 63.5 \\
\hline 17 & $\begin{array}{l}\text { Showering, or washing one's genitals/private parts, after sex keeps a person from } \\
\text { getting HIV. }\end{array}$ & 312 & 72.6 \\
\hline 18 & All pregnant women infected with HIV will have babies born with AIDS. & 298 & 69.3 \\
\hline 19 & $\begin{array}{l}\text { People who have been infected with HIV quickly show serious signs of being } \\
\text { infected }\end{array}$ & 299 & 69.5 \\
\hline 20 & A woman cannot get HIV if she has sex during her period. & 342 & 79.5 \\
\hline
\end{tabular}

Student's response was considered to have good HIV/AIDS knowledge if the respondent scored greater than or equal to 13.6 (mean knowledge value) and poor if less than 13.6. Nearly half 209(48.6\%) of the respondents had poor level of knowledge (Fig. 2). 


\section{HIV/AIDS preventive self-efficacy of the respondents}

In this section HIV/AIDS preventive self - efficacy scale with 26 items used. The mean of each question was calculated with SD. The overall mean of HIV/AIDS preventive self-efficacy of the respondents were found to be $74.58 \pm 19.98$ SD in which it was $71.38 \pm 18.01$ and $81.21 \pm 22.18$ for males and females respectively. The total sum for the self-efficacy ranged from 26 to 130 . Of total respondents only two participants were very sure in their abilities to perform all HIV/AIDS preventive self-efficacy (Table 6). 
Table 6

HIV/AIDS preventive self-efficacy among regular undergraduate students of Madda Walabu University Bale Zone, Southeast Ethiopia February 15-20/2020.

\section{Variables}

Mean SD

How sure are you of being able to say no when someone... suggests having intercourse

A1 ...someone you've known for 30 days or less?

$2.89 \quad 1.594$

A2...someone whose sexual history is unknown to you?

$3.04 \quad 1.474$

A3...someone whose drug history is unknown to you?

$3.13 \quad 1.445$

A4 ...someone you've known before?

$3.18 \quad 1.398$

A5...someone you would like to get involved with again?

$3.09 \quad 1.401$

A6...someone with whom you have had sex before?

A7...someone you need to fall in love with you?

A8...someone who puts pressure on you to have sex?

$2.96 \quad 1.388$

A9...someone with whom you have been drinking alcohol?

$2.93 \quad 1.414$

A10...someone with whom you have been using drugs?

$2.99 \quad 1.377$

A11...someone with whom you are very sexually aroused?

Total

$33.39 \quad 14.231$

\section{How sure are you of being able to...?}

B1...ask your boyfriend or girlfriend if he/she has used and injected drugs.

B2...discuss AIDS prevention with your boyfriend or girlfriend?

$3.26 \quad 1.374$

B3...ask your boyfriend/girlfriend about his/her past?

Total

$9.13 \quad 4.106$

How sure are you of being able to...?

$\mathrm{C} 1$...use a condom each time you have sex?

$2.80 \quad 1.401$

C2...use a condom correctly?

$3.00 \quad 1.382$

C3...use a condom during sex after you have been drinking alcohol?

$2.54 \quad 1.309$

C4...use a condom during sex after you have been using simulative drug? (Shisha/Gaya Hashish, Cocaine and others)

C5...insist on using a condom during sex, even when your boyfriend/girlfriend would rather not use one?

C6...refuse to have sex if your partner does not agree to use a condom? 
Table 6

continued...

\begin{tabular}{|lll|}
\hline C7... always has enough money to buy condoms? & $\mathbf{2 . 8 4}$ & $\mathbf{1 . 3 7 1}$ \\
\hline C8...go to pharmacy to buy condoms? & 2.80 & 1.389 \\
\hline C9... not have sexes until you are married? & 2.94 & 1.438 \\
\hline C10 ... have sex only with one person during your whole lifetime? & 3.03 & 1.480 \\
\hline C11 ... talk to your father about sexual topics? & 2.22 & 1.331 \\
\hline C12 ... talk with your mother about sexual topics? & 2.18 & 1.357 \\
\hline Total & 32.09 & 16.327 \\
\hline
\end{tabular}

As Fig. 3 shows, after computing the variables and categorized the level of prevention, more than half 220(51\%) of the participants found to had good level of HIV/AIDS preventive self-efficacy which scored greater or equal to mean value and $210(49 \%)$ participants were found to had poor level of HIV/AIDS preventive self-efficacy (Fig. 3).

\section{Factors associated with preventive self-efficacy}

In this study the association of different background factors of the respondents with HIV/AIDS preventive selfefficacy was investigated using bivariate and multivariable logistic regression analysis. On bivariate analysis students' sex, origin of residence, field of study, year of study, preparatory accomplishing, drinking alcohol, had injected drugs, go to night clubs, ever had tested for HIV and ever had watched pornography were found to be significant during bivariate analysis.

Variables with p-value less than 0.20 in bivariate analysis and considered important variable were entered into multivariable logistic regression. During multivariable logistic regression being female [AOR $=1.76(1.04-2.81)]$, being in health science student $[A O R=1.92(1.10-3.36)]$, years of study $[A O R=2.77(1.55-4.94)]$, drunk alcohol $[A O R=2.9(1.61-5.23)]$ were associated with higher preventive self-efficacy. Whereas, watching pornography were associated with lower preventive self-efficacy $[A O R=0.53(0.33-0.85)]$ (Table 7). 
Table 7

Bivariate and Multivariate Logistic regression analyses of factors associated with HIV /AIDS preventive self-efficacy among study participants at Madda Walabu University Bale Zone, Southeast Ethiopia February $15-20 / 2020$.

\begin{tabular}{|c|c|c|c|c|}
\hline \multirow[t]{3}{*}{ Variables } & \multicolumn{2}{|c|}{ Preventive self-efficacy } & \multirow[t]{3}{*}{ COR $(95 \% \mathrm{Cl})$} & \multirow[t]{3}{*}{ AOR $(95 \% \mathrm{Cl})$} \\
\hline & Poor & Good & & \\
\hline & $\mathbf{N}(\%)$ & $\mathbf{N}(\%)$ & & \\
\hline \multicolumn{5}{|l|}{ Sex } \\
\hline Female & $53(12)$ & $87(20)$ & $1.94(1.28-2.93)$ * & $1.76(1.04-2.81)$ * \\
\hline Male & $157(37)$ & 133(31) & 1.00 & 1.00 \\
\hline Origin of residence & $98(23)$ & $127(29)$ & $1.56(1.07-2.28)$ & $1.27(0.83-1.95)$ \\
\hline \multicolumn{5}{|l|}{ Urban } \\
\hline Rural & $112(26)$ & $93(22)$ & 1.00 & 1.00 \\
\hline \multicolumn{5}{|l|}{ Field of study } \\
\hline Health science & $41(10)$ & 75(17) & $2.13(1.37,3.31)$ * & $1.92(1.10-3.36)$ * \\
\hline Non-health science & $169(39)$ & $145(34)$ & 1.00 & 1.00 \\
\hline \multicolumn{5}{|l|}{ Year of study } \\
\hline II & $31(7)$ & $88(20)$ & $3.19(1.88-5.41)$ * & $2.77(1.55-4.94)$ * \\
\hline III & $106(25)$ & $67(16)$ & $0.71(0.45-1.12)$ & $0.71(0.44-1.16)$ \\
\hline IV and above & $73(17)$ & $65(15)$ & 1.00 & 1.00 \\
\hline Preparatory accomplishing & $178(42)$ & $176(41)$ & 1.00 & 1.00 \\
\hline Governmental & $32(7)$ & $44(10)$ & $1.39(0.84-2.29)$ & $1.21(0.69-2.12)$ \\
\hline \multicolumn{5}{|l|}{ Non-governmental } \\
\hline \multicolumn{5}{|l|}{ Drinking alcohol } \\
\hline Yes & $40(9)$ & $60(14)$ & $1.59(1.01-2.51)$ * & $2.9(1.61-5.23) *$ \\
\hline No & $170(40)$ & $160(37)$ & 1.00 & 1.00 \\
\hline Ever had tested for HIV & $111(26)$ & $151(35)$ & $1.95(1.32-2.89)$ & $1.47(0.94-2.31)$ \\
\hline \multicolumn{5}{|l|}{ Yes } \\
\hline No & 99(23) & 69(16) & 1.00 & 1.00 \\
\hline Ever had injected drugs & $35(8)$ & $21(5)$ & $0.53(0.3-0.94)$ & $1.41(0.74-2.703)$ \\
\hline Yes & & & & \\
\hline
\end{tabular}

* p-value less than 0.05; COR Crude Odds ratio; AOR Adjusted Odds ratio 


\begin{tabular}{|c|c|c|c|c|}
\hline \multirow[t]{3}{*}{ Variables } & \multicolumn{2}{|c|}{ Preventive self-efficacy } & \multirow[t]{3}{*}{ COR $(95 \% \mathrm{Cl})$} & \multirow[t]{3}{*}{ AOR $(95 \% \mathrm{Cl})$} \\
\hline & Poor & Good & & \\
\hline & $N(\%)$ & $\mathrm{N}(\%)$ & & \\
\hline No & $175(41)$ & 199(46) & 1.00 & \\
\hline Go to night clubs & $12(3)$ & $25(6)$ & $2.12(1.03-4.33)$ & $1.28(0.55-2.97)$ \\
\hline \multicolumn{5}{|l|}{ Yes } \\
\hline No & 198(46) & 195(45) & 1.00 & \\
\hline \multicolumn{5}{|c|}{ Ever had watched pornography } \\
\hline Yes & $93(22)$ & 74(17) & $0.64(0.43-0.94)$ * & $0.53(0.33-0.85)$ * \\
\hline No & $117(27)$ & 146(34) & 1.00 & 1.00 \\
\hline Knowledge level & $99(24)$ & $110(25)$ & $1.21(0.77-1.64)$ & $1.42(0.87-2.33)$ \\
\hline \multicolumn{5}{|l|}{ Poor level } \\
\hline Good level & $111(26)$ & $110(25)$ & 1.00 & 1.00 \\
\hline
\end{tabular}

\section{Discussion}

This study has attempted to assess the level of HIV /AIDS preventive self-efficacy and associated factors among regular undergraduate students of Madda Walabu University. The finding showed that the mean level of HIV/AIDS preventive self-efficacy of the students were 74.58 (SD \pm 19.98$)$. The result of this study was in line with the study conducted in Taiwanese on 734 high school students $74.45(\mathrm{SD} \pm 17.05)\left({ }^{(13}\right)$, however the finding was lower than the study conducted in Turkey on 507 University students $87.66(\mathrm{SD} \pm 23.94)^{(12)}$ and study conducted on 962 Mexican adolescents from 60 public health centers $95.14(\mathrm{SD} \pm 25.80)^{(11)}$.

The possible reason for the discrepancies in HIV/AIDS preventive self-efficacy may be due to difference in the study place. Further reason may be data about adolescents collected from high school students and public health center might be different from universities. The difference in health education regarding HIV/AIDS and ways of delivering the education might also be the reason for difference. From my view, in Ethiopia, issue of HIV/AIDS is neglected in this time, in which there is limited public mass media alerting the students regarding HIV/AIDS, might contribute for difference in the finding.

This study reported (51.4\%) of respondents were knowledgeable about HIV/AIDS. This finding was higher than study conducted on Bahir Dar university $(45.7 \%){ }^{(21)}$ and study conducted on Maddawalabu University $(49.37 \%)$ (27). However, it was lower than study conducted on undergraduate students of Addis Ababa University (66\%) (28). The difference in the finding may be due to difference in sample size and study period.

Of total respondents in the study area, 160(37.2\%) participants were found to be sexually active. This finding was lower than study conducted in Turkey University $(52.7 \%)^{(12)}$ and Wollega University, Ethiopia(49.1\%)(17). 
However, higher than study conducted among students of Debre Berhan University (36.5\%) (29) and Addis Ababa University $(26.8 \%)^{(28)}$.

The mean age of sexual debut of the participants in the study area was $18.21 \pm 2.11$ in which it was higher for males $(18.55 \pm 2.11)$ than for females $(17.28 \pm 1.89)$. The finding was higher than study conducted in Turkey University $(17.8 \pm 1.98)$ in which it was $17.6 \pm 2.00$ years for males and $19.0 \pm 1.35$ years for females ${ }^{(12)}$ and related study conducted in Wollega University $(17.2 \pm 2.15)$ in which it was $17.5( \pm 2.21)$ and $16.9( \pm 3.10)$ years for males and females respectively ${ }^{(17)}$ and students of Addis Ababa university 17.4 years ${ }^{(28)}$. The discrepancies may be due to difference in study place and period. The other reason may be difference in sociocharacteristics and behavior of the students in this different campus.

Among socio-demographic characteristics sex was found to be significantly associated with HIV/AIDS Preventive self-efficacy. According to this study, females were 1.76 more likely to had higher HIV/AIDS preventive self-efficacy when compared to males. In this study the mean HIV/AIDS Preventive self-efficacy was 71. $38 \pm 18.01$ and $81.21 \pm 22.18$ for males and females respectively. This is consistent with the study conducted in Turkey University ${ }^{(12)}$ and among Taiwanese adolescents ${ }^{(13)}$. The reason may be due to female's precaution on sexual intercourse and fearing of suffer from the complication after sexual intercourse. The other reason may be due to family support for females, in which most of the time females were oriented on sexual issues than males due to the family considered them as victim. In the study area there was a restriction of female student's movement due to unsupported from communities' custom. However, male students were free for movements and involved in activities out of the campus. Therefore, this may be the reason for the difference in HIV/AIDS preventive self-efficacy between males and females in this study area.

This study revealed that field of study was significantly associated with HIV/AIDS Preventive self-efficacy. In this study health science students were almost 2 times more likely to have higher HIV/AIDS preventive selfefficacy when compared to non-health science students. The finding was consistent with study done in university of Turkey ${ }^{(12)}$. The probable reason may be health science students were more informed about reproductive health and they could get HIV/AIDS education in their course. The other reason maybe they had course like family planning which supports them to use condom in consistent way than non-health students. This study found drinking alcohol was associated with higher HIV/AIDS preventive self-efficacy. The finding was inconsistent with study conducted on Taiwanese adolescence ${ }^{(13)}$. Literatures showed there were association between substance use and risks for acquiring HIV/AIDS infection ${ }^{(30)(16)(15)}$. The reason may be substance user's inability to controlling their emotion after utilization of the substances. However, in this study area participants who were drinking alcohol had 2.9 times more likely had higher HIV/AIDS preventive selfefficacy compared to those who were not drinking. The probable reason may be participants who drinking alcohol may not fear for talking about sexual issues freely before having the sexual intercourse with their counterpart than who were shying to talk about the sexual and related issues but involved in practice.

The study found that there was significant association between exposure to pornography and HIV/AIDS preventive self-efficacy. Participants who had ever watched pornography were 0.53 times less likely to have higher HIV/AIDS preventive self-efficacy compared to who were not ever had watched. Exposure to pornography may be the risk for infection increase. This idea is supported by study conducted on Debre Berhan University in which pornography exposure shows significant association with risky sexual behavior ${ }^{(14)}$ and qualitative study 
carried out in higher educational institution of Ethiopia were reported exposure to pornography as a problem for the infection increases ${ }^{(16)}$. The reason may be increasement in internal motivation of the students towards sexual intercourse after watching the pornography which push them unintentionally to be involved in sexual activities. The other may be just due to their age, adding pornography on their fire age will put them in risk for this infection. Therefore, exposure to pornography was associated with HIV/AIDS preventive self-efficacy and risk for infection increase.

\section{Conclusion And Recommendations}

The mean HIV / AIDS preventive self-efficacy of the participants in this study area were found to be low. Variables like sex, field of study, year of study, drinking alcohols and ever had watched pornography were found to be factors associated with HIV/AIDS preventive self-efficacy. The study found more than half of the participants (51.4\%) were knowledgeable about HIV/AIDS. However, the finding showed significant number of participants involved in risk taking behavior.

Families recommended to well involving in discussing about HIV/AIDS and sexual related issues with their sons/daughters freely. Madda Walabu University management office, office worked with issue of HIV/AIDS and clubs should work hard to increase the student's level of HIV/AIDS preventive self-efficacy. Besides that, all staff should cooperative in educating their students to boost their self-efficacy. The state policy makers recommended to revise their policy concerning HIV/AIDS services at university and communities' level at large. And, professionals and researchers should work more in areas concerning HIV/AIDS preventive self-efficacy in communities' level.

\section{Abbreviations}

USAID: United States Agency for International Development; UNICEF: United Nations Children's Fund, MOE: Ministry of Education; WHO: World Health Organization; SEA: Self -efficacy Assessment; SPSS: Statistical Package of Social Science; Cl: Confidence interval; COR: Crude odds ratio, AOR: Adjusted odds ratio, AAU: Addis Ababa University; MWU: Madda Walabu University

\section{Declarations}

\section{Acknowledgments}

We would like to thank Addis Ababa University collage of Health Science for funding. We also like to thank the participants in this study, data collectors and supervisors for all their cooperation. In addition, we would like to acknowledge all those supported us during the research process.

\section{Authors' contributions}

All authors made substantial contributions to conception and design, acquisition of data, or analysis and interpretation of data; took part in drafting the article or revising it critically for important intellectual content; agreed on the journal to which the article will be submitted; gave final approval of the version to be published; and agree to be accountable for all aspects of the work. 


\section{Funding}

Addis Ababa University

\section{Availability of data and materials:}

The data set analyzed during the current study will be available from the corresponding author on reasonable request.

\section{Ethical consideration}

Ethical approval was obtained from the ethical review committee of Department of Midwifery, school of Nursing and Midwifery Institutional Review Board, Addis Ababa University. Permission was obtained from of Madda Walabu University management and respective schools. Voluntary written consent was obtained from each study participants. To protect students' confidentiality and increase chances of releasing honest information, questionnaires was kept anonymous and class was designed as students were never read over others' shoulder.

\section{Consent for publication}

Not applicable.

\section{Competing interests}

The authors declare that they have no competing interests.

\section{References}

1. Bandura A. Social cognitive theory. Psychol Rev. 2001;1-26.

2. Dan R. Denson RV and RE. Self-Efficacy and AIDS Prevention for University Students. Int J Adolesence Youth. 1994;5:105-13.

3. Rosina Cianelli, Natalia Villegas, Brian E. McCabe1, Lila de Tantillo and NP. Self-Efficacy for HIV Prevention among Refugee Hispanic Women in South Florida Rosina. J Immigr Minor Heal. 2017;19(4):905-912.

4. UNICEF. Annual Report 2018.

5. WHO. Global HIV and AIDS statistics 2017.

6. MOE. Education Sector Response to HIV and AIDS , Learning from Good Practice In Ethiopia. 2012. 1-66 p.

7. Andrew PO, Bhuiyan A, Mawson A, Buxbaum SG, Sung JH, Shahbazi M. HIV/AIDS Knowledge of Undergraduate Students at a Historically Black College and University. MDPI Dis. 2018;6(98):1-8.

8. CDC Vital signs. HIV Among youth in US November 2012.

9. Rabani-Bavojdan et al. The Effectiveness of the Harm Reduction Group Therapy Based on Bandura's SelfEfficacy Theory on Risky Behaviors of Drug-Dependent Sex Worker Women. Addict Heal [Internet]. 2017;9(3):175-82. Available from:

http://www.ncbi.nlm.nih.gov/pubmed/29657698\%0Ahttp://www.pubmedcentral.nih.gov/articlerender.fcgi? artid=PMC5894797 
10. Devika Mehra, Per-Olof Ostergem BE and AA. Inconsistent condom use among Ugandan University students from a gender prespective:a cross-sectional study. Glob Health Action. 2014;7:22942.

11. López-Rosales F, Moral-De la Rubia J. Validation of a self-efficacy scale for AIDS prvention among adolesence. Salud Publica Mex. 2001;43:421-32.

12. Bulduk S, Erdo S. Reliability and validity of a Self-efficacy Scale for AIDS Prevention among Turkish university students. Int J Hum Sci Availablehttp//www.insanbilimleri.com. 2008;5(2).

13. Yi-Hi Lee, Ali Salman and TC-J. Gender differences in HIV/AIDS Preventive Self-Efficacy Among Taiwanese Adolescents. AIDS Educ Prev. 2016;28(1):77-89.

14. Bowser D HK. Exploring evidence for disrespect and abuse in facility-based childbirth. Boston: USAIDTraction Project, Harvard School of Public Health and University Research Co., LLC; 2010;

15. Mulu W, Abera B, Yimer M. Prevalence of Human Immunodeficiency Virus infection and associated factors among students at Bahir Dar University. EthiopJHealth Dev. 2014;28(3):170-7.

16. Sahile Z, Mekuria M, Yared A. Comprehensive HIV / AIDS Knowledge and Sexual Behavior among University Students in Ambo, Central Ethiopia: Implication to Improve Intervention. J Sex Transm Dis. 2015;6.

17. Negeri EL. Determinant of Risky Sexual Bavior, Relation Between HIV Risk Perception and Condom Utilization among Wollega University in Nekemte Town,West Ethiopia. Sci Technol Arts Res J. 2014;3(3):75-86.

18. Al S et. Determinants of women's satisfaction with maternal health care: a review of literature from developing countries. BMC Pregnancy Childbirth. 2015;15-97.

19. Madda Walabu Registrar office report. 2020;

20. Kasen S, Vaughan RD, Walter HJ. Self-Efficacy for AIDS Preventive Behaviors among Tenth Grade Students. Health Educ Q. 1992;19(2):187-202.

21. Mulu W, Abera B, Yimer M. Knowledge, attitude and practices on HIV / AIDS among students of Bahir Dar University. Sci J Public Heal. 2014;2(2):78-86.

22. Sayles etal. Factors Associated With self-Efficacy For Condom Use and Sexual Negotiation Among South African Youth. J Acquir Immune Defic Syndr. 2006;42(2):226-33.

23. Khalajabadi FF, Mahdi Mohammad Akhond MS and AA. HIV/STI Risk-Taking Sexual Behaviours and Risk Perception Among Male University Students in Tehran: Implications for HIV Prevention among youth. JBiosocSci. 2018;(50):86-101.

24. Fesehatsion K. Knowledge, attitude, risk behavior on HIV/AIDS and willingness to participate in an HIV vaccine trial among high school teachers in addis ababa city, ethiopia. Unpubl Pap. 2002;

25. Michael P.Carey KEES. Development and Psychometric Evaluation of Brief HIV Knowledge Questionnaire. AIDS Educ Prev. 2008;14(2):172-82.

26. Zometa CS, Robert D, D KM, Wayne W, Simán SR, Ann D. Translation, Cross-Cultural Adaptation and Validation of an HIV/AIDS knowledge and attitudinal instrument. AIDS Educ Prev. 2007;19(3):231-44.

27. Obsa AG, Weldihanes B. Knowledge and Self- Efficacy on Hiv / Aids among Undergraduate Students of Maddawalabu University , Southeast Ethiopia. Glob J HUMAN-SOCIAL Sci G Linguist Educ. 2017;17(1). 
28. Woldeyohannes D, Asmamaw Y, Sisay S, Hailesselassie W. Risky HIV sexual behavior and utilization of voluntary counseling and HIV testing and associated factors among undergraduate students in Addis Ababa , Ethiopia. BMC Public Health [Internet]. 2017;1-10. Available from:

http://dx.doi.org/10.1186/s12889-017-4060-y

29. Muluken Dessalegn MW. Predictors of consistent condom use among University students: Hierarchical Analysis Debre Berhan, Ethiopia. Glob J Med Public Heal. 2012;1(4).

30. Namaitijiang Maimaiti, Muharrem Metin Sener HHT. Risk Behaviors Associated With HIV/AIDS Among University Students In Konya. Malaysia J Public Heal Med. 2017;17(2):52-61.

\section{Figures}

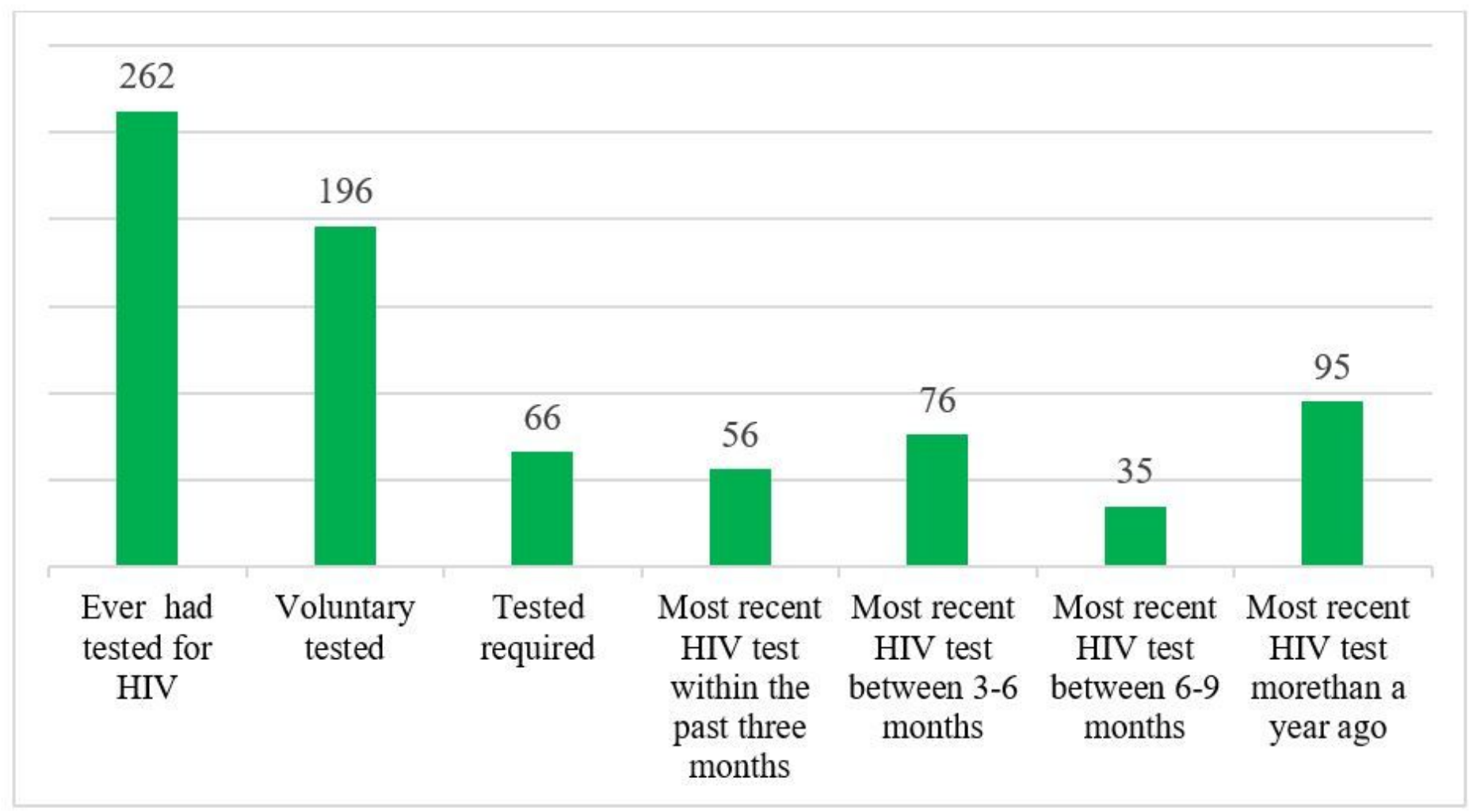

\section{Figure 1}

Number of participants ever tested for HIV, types of test and duration of most recent test done at Madda Walabu University Ethiopia February 15-20/ $2020(\mathrm{~N}=430)$. 


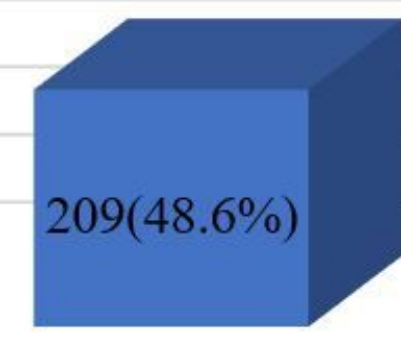

Poor level of knowledge

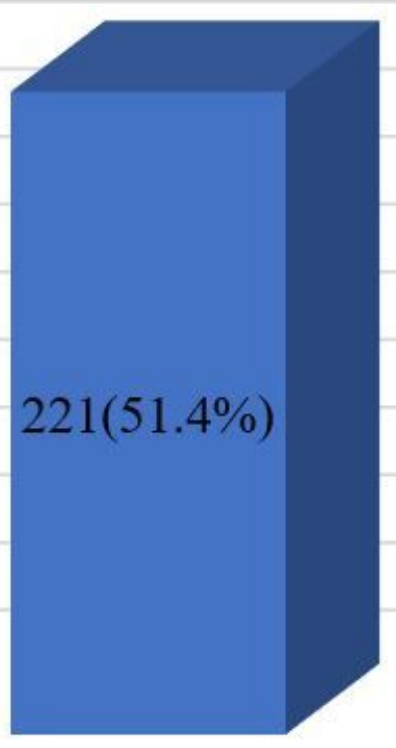

Good level of knowledge

\section{Figure 2}

Level of HIVAIDS Knowledge among regular undergraduate students of Madda Walabu University Bale Zone, Southeast Ethiopia February 15-20/ 2020.

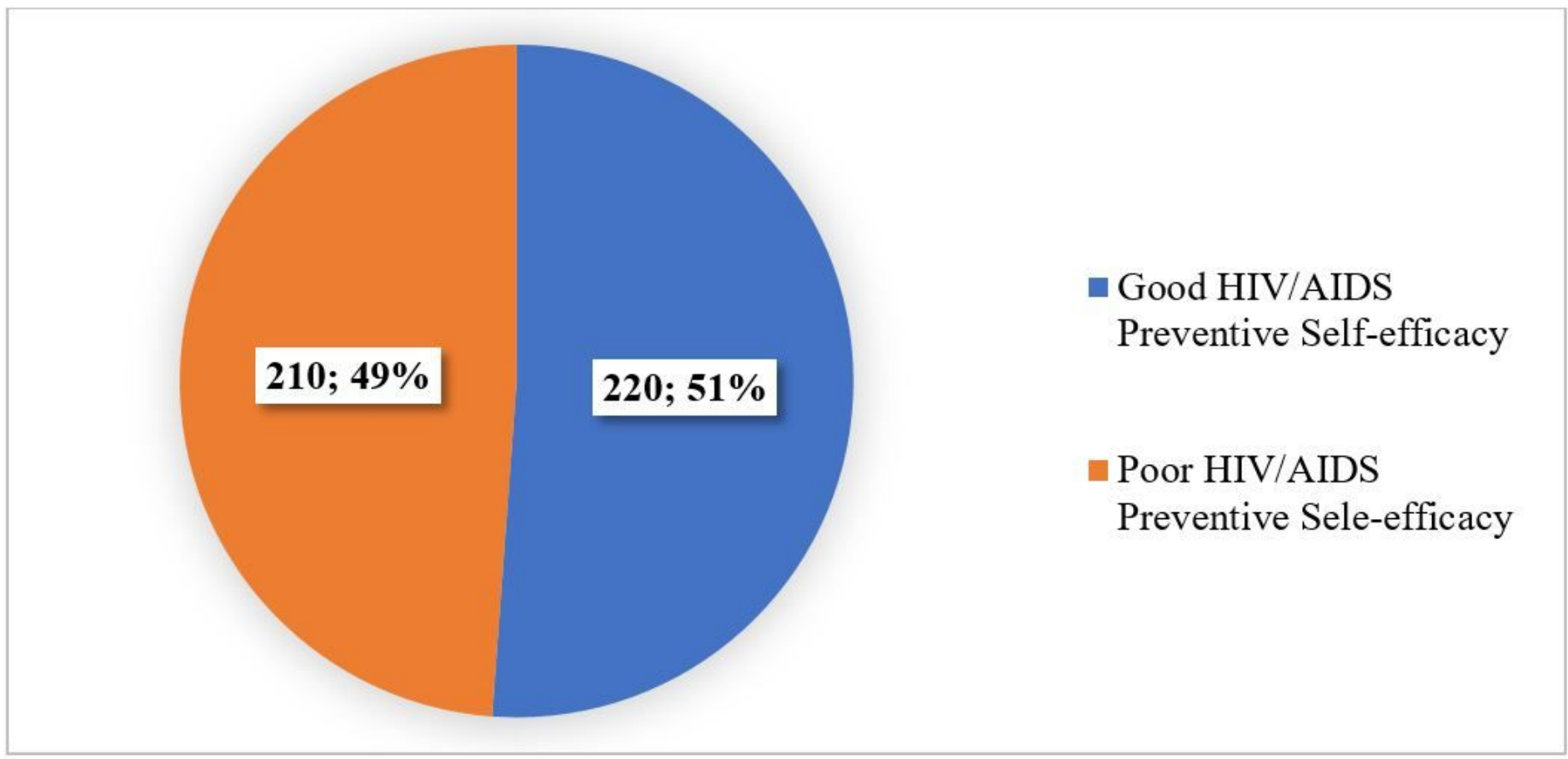

Figure 3 
Level of HIV / AIDS preventive self-efficacy among regular undergraduate students of Madda Walabu University Bale Zone, Southeast Ethiopia February 15-20/2020.

\section{Supplementary Files}

This is a list of supplementary files associated with this preprint. Click to download.

- STROBEcrosssectionalchecklist.docx 